\title{
Negativity in Communism: Ontology and Politics
}

\author{
Artemy Magun \\ Professor of Democratic Theory, European University at Saint-Petersburg \\ Associate Professor, Saint Petersburg State University \\ Correspondence Address: Gagarinskaia Street 3, St. Petersburg, Russian Federation 191187 \\ Email: amagun@eu.spb.ru
}

\begin{abstract}
The article addresses the notion of communism with a special angle of factuality and negativity, and not in the usual sense of a futurist utopia. After considering the main contemporary theories of communism in left-leaning political thought, the author turns to the Soviet experience of an "actually existing communism." Apart from and against the bureaucratic state, a social reality existed organized around res nullius, that is, an unappropriated world that was not a collective property, as in the case of res publica. The alienation from things and from the state resulted not only in the sense of oppression, but in a new culture of a paradoxical "communality" (A. Zinoviev), where the "Other," be it a thing or a person, appears rather as ground, not figure. This culture of a non-thematic gaze led to a formation of a communality as a given, and not as a utopian desideratum. I claim that this is a major difference between the current Western society and a post-Communist society. The former is more solidary and collectivist, but only consciously and deliberately so, operating from an individualist ontology, while the latter is individualist, but with an assumption of the "Other" as a pre-given fact. In this chiasmus, both "communisms" are problematic, so that an alternative model of individuation (Virno), rather than the atomization of an assumed collectivity, would be preferable.
\end{abstract}

Keywords: communism, negativity, res nullius, late Soviet society, alienation.

\section{Communism that is and communism to be}

"Communism" is a concept that, from the very emergence of its present meaning during the period of the French revolution ${ }^{1}$, was meant to be a more radical and also more down-to-earth alternative to the idealistic and idyllic slogans of the Jacobins (liberty, equality, fraternity, etc.). Unlike the former, "communism" includes a reference to economy and, more precisely, to a society without private property. This materialist content was later reaffirmed by Marx who, after a period during which he had rejected the concept altogether (Marx, 1975a), expressed allegiance to it only with the caveat that "Communism [was for him and Engels] not a state of affairs which is to be established, an ideal to which reality [will] have to adjust itself" and that they called "communism" "the real movement which abolished the present state of things" (Marx, Engels, 1975b: 37). I emphasize the term "abolished"; a good Hegelian, Marx accepted communism not as an ideal but as a real negation, a force opposed to the established state of things which is latent or "spectral" as yet.

\footnotetext{
(C) Magun A., 2014

(c) Centre for Fundamental Sociology, 2014

1. By Restif de la Bretonne, then by German Jacobins; see: Grandjonc, 1983.
} 
Communists, with their "criticism of the Earth" (Marx, Engels, 1975a: 177) belong to the revolutionary branch of the Romantic movement that aspired to reverse the usual spiritualist orientation of humanity away from the Earth to Heaven, to redirect it into the depths of Earth, and towards the depth of matter and the prose of life.

Thus, Hölderlin, who belonged to German Jacobins, mentioned a need for the "communism of spirits" (Hölderlin, 1989: 239-241), this being one of the very first usages of the word, and notes in his "Remarks on Antigone" that the tendency of the Moderns, in contrast to that of the Ancients, is the tendency from the sky down to the soil, because the Ancients still "had" this soil, while the Moderns have yet to institute it (Hölderlin, 1988: 113-114). Hölderlin names this tendency a "categorical revolution [Umkehr]". Before Marx, and like Marx, he insists that the "materialist" tendency goes along with the reverse, negative orientation of the movement.

In France, this tradition is followed by another left-wing romantic, Jules Michelet. He writes in his History of the French Revolution that "One has to dig deeper than Dante and to uncover, inside the Earth, the deep foundation of people on which the colossus [of monarchy] is built" (Michelet, 1979: 67).

The same tendency was continued a hundred years later during the Bolshevik revolution in Russia. One of its early supporters, the poet Alexey Gastev, wrote: "We will not aspire to these heights that are called 'heaven.' Heaven is a creation of the idle, lazy, and timid people. Let us rush down! Together with fire, metal, and gas, and steam, let us dig mines, let us drill the largest tunnels in the world, let us empty in the bowels of the earth the untouched old layers" (Gastev, 1971: 138). The tradition was later continued by Gastev's younger friend and disciple, Andrey Platonov, whose work we will discuss below.

All of this is important to argue against the dominant liberal-conservative perception of Soviet communism as one more ideocratic dictatorship ${ }^{2}$. If it was an Enlightenment educational regime, it was such only for the reason that it emerged out of a materialist struggle against idealism - the only properly idealistic philosophical state is, of course, a liberal state.

Nevertheless, the ambiguity of the concept between a vision and an ontological statement remained, even for Marx himself who certainly had a vision, although vague, of a future communist society, "where nobody has one exclusive sphere of activity but each can become accomplished in any branch he wishes, society regulates the general production and thus makes it possible for me ... to hunt in the morning, fish in the afternoon, rear cattle in the evening, criticize after dinner" (Marx, Engels, 1975b: 37) and where "the free development of each" would be "the condition for the free development of all" (Marx, Engels, 1976: 506).

This ambiguity already caused trouble in Marxist theory of the early $20^{\text {th }}$ century. The materialist side of communism as a real process was understood in a positivistic way as being governed by objective laws, and many communists were forced to distinguish between the "scientific" and "ethical" trends of Marxism.

2. Such as represent, in (post-)Soviet studies, B. Groys, M. Ryklin, E. Dobrenko, and others. 
Today, in the early $21^{\text {st }}$ century, we return to the same ambivalence that lies at the heart of the concept and of the movement of communism. For a long time, serious Marxists have recognized that the Soviet Union was not only far from the communist utopia (which it promised for the future), but, in most cases (because of the role of bureaucracy), also far from communism as a process. However, the initial vagueness of the utopian aspect of the teaching prevented most Marxists from seriously exploring the notion of communism.

Therefore, by the time that the Soviet and pro-Soviet Marxism died "in itself", and perhaps for the first time since Marx, serious attempts emerged to conceive "communism" at the level of contemporary philosophy and of the existing political-economic condition. First of all, because of the need of a counter-argument against the victorious liberal state after the disappearance of the communist utopia, the properly democratic elements started dying out and gave way to the victory of the expert-driven managerial authoritarianism. Secondly, because of the newly emerging chance of projecting the notion of communism into the open future, without associating it with any actual historic regime.

Indeed, after the victory of the liberal vision of society, communism sounded once again as the only viable alternative to the idealistic models of human togetherness, whether understood as the representative state, the rule of law, or a social contract combining individuals into a whole. This idealistic liberal unity remains relative; it hypostasizes an individual who originally exists by itself and only then enters a society. Excesses of this model are the melancholic and moralistic individualism of the bourgeois subject, the crushing of the "general will" in the Rousseauist republic, and especially nationalism as a collective egoism which unites individualism and collectivism as they exist in the bourgeois society and ideology.

There should be a way to conceive a stronger totality which would not involve a transcendent principle of unity (like God), but would nevertheless allow for an infinite relationship of a member to the whole which it would "run through". When Marx described the effects of the bourgeois revolution, he noted that this "political revolution dissolves civil society into its elements without revolutionizing these elements themselves" (Marx, 1975b: 160). The goal of a new revolution would thus be a chemical or even nuclear dissolution of the social fabric which would allow it setting off from the fixed opposition of egoism and idealism, and which would strive for a new kind of unity.

In such a totality, elements would interweave and interpenetrate, and would be free in the sense of a "virtuosity" (Virno, 2004) and free play, instead of the liberal freedom within pre-set boundaries. Hegel had already expressed something like this with his concept of "absolute" (i.e., "the bacchanalian revel, where not a member is sober; and ... [at the same time] the revel is just as much a state of transparent unbroken calm"). However, Hegel thought that the revolution had been superseded by the organic state and was rightly accused of conservative tendencies. His followers, the young Hegelians and primarily Marx, looked for such an absolute from the side of the substance (underesti- 
mated by Hegel, in their view), and emphasized its negative, dissolving force which they reoriented against Hegel's own philosophy.

It is important to note that, unlike the recurrent bourgeois apologies of solidarity (communitarianism in USA, "civil society" in the recent sociological and political discourse), communism, even if aimed against private property, is not a univocal "collectivism". Both Marx and recent theorists of communism actually emphasize its negative predicates, oriented at least at the dissolution of already existing social units. Communism is a vision of society which justifies the forces of social dissolution acting in every society, while liberalism uses these same forces as an argument for its dualism of individual and state $^{3}$. But, in the context of communism, these forces are seen as revolutionary, to wit, as social forces of auto-dissolution that bear energies of collective liberation. The totality/ commonality that "communism" promises proceeds not only from the positively defined goal of an activity (here, a unitary collective subject would suffice) but rather as a negative unity of the suspended, dissolved multitude who are co-ordinating among themselves, so to speak, "by default."

To return to our own time at the end of 1980s, two philosophical concepts of communism emerged almost simultaneously in the French school of post-metaphysical philosophy, those of Jean-Luc Nancy and Alain Badiou. Both of these philosophies were obviously created in the wake of Soviet communism and propose, in contrast with the latter, a new vision of communism not having to do with a party state organization of power or with the socialist state capitalist economy.

I will briefly reiterate these two approaches. Nancy insists on the ontological, pluralistic character of community, and on communism as a transcendental predicate of the being itself. This philosophy is thus a philosophy that reproduces transcendence and "extasy" within the immanence of human and non-human interrelations. Nancy speaks against the understanding of a community as strictly immanent, since in this case, it would form one unitary subject ("people", "nation"), prepared to rationally organize and distribute objects. While Nancy's ontological communism is often criticized as an impractical and non-revolutionary concept, the value of his approach is the insistence on the subversive "ecstatic" nature of communism and community, compared against the naively idealistic liberal and socialist apologies of solidarity.

A. Badiou, in his work Being and Event (Badiou, 2006), gives a political and metaphysical interpretation of the theorem of Paul Cohen, a theorem that constructs a "generic" set, or a subset that escapes, "runs through" any positive determinations, identifications that would be available within a given set. For Badiou, this mathematical form can help in the conception of the task of a militant subject; this subject, being loyal to a certain emancipatory event, has to gradually form a generic set, "selecting" things and occurrences that, in his view, are linked to the indescribable and unidentifiable event. The event, in its turn, is an explosion of an unrecognized multiplicity ("singular" elements) within an orderly world of mathematical sets. In his more recent work, Badiou speaks of

\footnotetext{
3. See Kant's notion of "asocial sociability", in: Kant, 1991: 41-53.

4. See most importantly The Inoperative Community (Nancy, 1991).
} 
communism as an "idea" (in the Kantian sense of an orienting principle); what already happened in mathematics and philosophy should now be further tested and proven in the political praxis.

It should be noted that despite their political proximity and the defense of what is commonly thought to be a vain utopia, the two theories have opposite tendencies. Nancy, like Marx, points at the unchangeable ontology which provides a certain angle from which to view the current social reality. On the contrary, communism for Badiou is a modus operandi of a subject, an image or an idea of what we can and should do, even though he also cannot escape an objective, ultra-ontological justification, which is the Event (which in itself is not yet "communist" in its content, but revolutionary).

It is noteworthy that both authors describe communism in negative, almost apophatic terms (transcendence or "extasy", for Nancy; escape of existing categories, for Badiou). In a recent text on communism, ${ }^{5}$ Nancy adds that communism only enters the agenda in the periods where the existing communities are being dissolved. This observation is a very important development of his theory. As for Badiou, the case is more complex for two reasons. He emphasizes that, even though the descriptions of the event and of the generic procedure are negative, their actuality is always an effect of an affirmation; they are thus "subtractive" and not simply "destructive" (Badiou, 2006: 407-408) ${ }^{6}$. Such denial of the substantiality of the negative in Badiou is problematic since the force that would "abolish the present state of things" is absent in his account, and this omission can lead to the coexistence of the newly recognized event with the whole repressive apparatus it subverts by its appearance. Moreover, this newly recognized event may well be dependent on such apparatus. Secondly, the missing negative force is needed to revert and return to the event, back from the positive forms that intervention and fidelity establish in its name. Badiou mentions that the event should remain in an intermediate state between being and non-being, although he does not demonstrate which subjective movement makes this possible.

In addition to these the two French philosophers, Italian leftist thought must be mentioned, in particular, the work of Paolo Virno. Virno, a proponent of communism from the philosophical and practical point of view, also gives communism an ontological status, though in a different vein than Nancy. For Virno, unlike Nancy, communism is immanent and not transcendent, and he understands it through the fundamentally social nature of thinking and/or working. For Virno, communism is already there, but one must emancipate it from the domination of capitalist governance and rationality, make it "public", and use it democratically. Virno cares about the subjectivity of communists more than Nancy. Nevertheless, like Nancy and unlike Badiou, he makes communism into an ontology, presenting an overly organic vision of the future transformation.

5. "Community - koinonia, communitas, Kommunsm - émerge à des époques de profondes transformations sociales et de troubles ou de destructions d'un ordre social" (Nancy, 2010: 201).

6. In the same vein, see Badiou's more recent theory of "subtraction" and "destruction", for instance, in: Badiou, 2007. 
In today's world, as in Marx's time, it is capital that is the most fervent creator of communism. In this context, Virno speaks of a "communism of the capital" (Virno, 2004: 97-98), which is based on the "general intellect" and "common places" indispensable in today's economy. It is within capitalism that new technologies are invented that seem to exclude complete private property, patenting, etc. The form of property of the means of production is no longer factually private. The flexibility of labor seems to question the division of labor. Leisure activities take more time and attention than work. But this "communism" remains subordinate to the laws of market and profit, and is compatible with them. The ideology of this factual communism remains liberal, that is, the actual communism is presented as a result of an artificial contractual relationship, while a free individual who, in Virno's persuasive conception, is still to be formed and cultivated qua personality, is instead presented by the ideology as a default pre-condition. Only a revolutionary event could invert this way of life and thought.

Such an event is not always directly envisioned by those who conceptualize communism. For Nancy, communism is a general matrix, and for Badiou, the event itself is always unpredictable and surprising. The current task is to be faithful to the events of the past such as the Parisian Commune, and the revolution of 1968. Italian post-operaists, Virno and Negri, are more practically oriented, but even they avoid speaking of revolution; they insist rather on negative strategies such as "exodus". This predominance of negative forms is in line with the infinite and indefinite kind of totality that communism represents, in opposition to democracy and the nation-state. However, Negri and Virno both explicitly deny that exodus is important because of its negativity; they follow Deleuze in insisting on the inherent positivity of any event, which leads them to think that the task of a revolution consists in giving full freedom to the already-existing creative force of the multitude. Against this claim, we should perhaps look for the revolutionary resources in the social negativity itself, as in the unconscious collective form of dissolution. Communism is revolutionary not as a supposedly positive form of society that must be affirmed against all others, but as a condition intimately tied up with the destruction of the status quo.

These ideas revive the old Marxian dilemmas of communism. If Soviet communism was wrong, if communism is a "hypothesis" (Badiou, 2009) as Badiou suggests, or a theorem yet to be proven (realized in practice), then it risks to be viewed as one more ideal. If communism is an ontological condition of humanity (even an "extatic" one), then it escapes historical determination and does not inspire much insurrectional activity. Finally, if there is a progressive tendency within capitalism, then how can it destroy its own presuppositions (namely, that of capitalism)? To escape this dilemma, we have to find a political definition of communism, and then to find something in actual reality that would "destroy the present condition" - precisely something that we do not see in Nancy, Badiou, or Virno.

7. See, for instance: Negri, Hardt, 2000: 131-132; see also an important critical article by Ernesto Laclau criticizing Negri and Hardt for the inattention to the negativity of history: Laclau, 2004. 


\section{2. "Communism" of the past and communism of the future}

The aforementioned philosophical debate leads us straight to the more specific historical condition of Central/Eastern European communism. If this was not communism, then (so liberals say), communism remains a utopian fantasy. If this was communism, then it certainly was an unpleasant, outdated socio-political regime in a poor and authoritarian country with an excessive push for collectiveness, which "goes against human nature," as Russian liberals like to say. The latter opinion is more widespread, and one normally speaks of the state of contemporary East and Central European European societies as "post-communism", assuming that communism had already taken place. Ironically, for citizens of the Soviet Union and other socialist countries, communism had always remained a utopia or a project to realize in the future. Thus, strangely, communism, at least in Soviet Union, was first in the future, then in the past, but never making it into the present (B. Groys even says, jokingly, that the making of communism into a fait accompli was the goal of "perestroika" (Groys, 2010)).

Thus, there are two common-sense perspectives; the first, that communism was an unrealistic utopia never achieved, and second, that the only possible realization of communism was a Soviet-style socialism, that is to say, "totalitarianism".

However, there is a third perspective, and it is shared by several interesting authors who have written on communism in the recent years. From this perspective, communism did really exist (and perhaps still exists), but it did not equal the Soviet-style state socialism at all. I have already mentioned the argument of Paolo Virno, who emphasizes the "communism" that is inherent in the capitalism but is subdued by its logic. Yet some analysts of "really existing socialism" also believed that communism existed under this regime, although it did not coincide with the official ideology or the accepted form of property. In Russia, it was Alexander Zinoviev, a Soviet dissident philosopher and émigré, and an author of an important treatise on Marx's dialectics who then turned to formal logic and, at the same time, to the violent critique of the Soviet regime expressed in semi-fictional satiric essays, who already held this view.

In his essay Communism as a Reality Zinoviev stated that communism really existed in Soviet Union, although it was not a politico-economic regime alternative to capitalism but a more profound societal regime of what he called "communality" - an excessively collective life of man which, he claimed, had been normally reduced in the West by "civilization" (Zinoviev, 1981: 56-59). The rest was a violent critique of the "communism" which vividly reminded the reader of the Western conservative theory of "masses" in the spirit of Le Bon, Tarde, and MacDougall. Zinoviev, logically enough, was skeptical about the perspectives of positively transforming Soviet communism, and this may explain his spectacular ideological u-turn in the 199os, when he sided with the reactionary and chauvinist "Communist Party of the Russian Federation" in its critique of Perestroika and of the liberal-democratic reforms. He became apologetic of the Soviet society, emphasizing that "it made the historical being of the people meaningful", and that in it, "citizens are guaranteed jobs, free medicine, retirement and other social goods", along with "powerful 
police forces and the military power to protect the country from a foreign attack". At that time, Zinoviev tentatively called the Russia regime a "communist capitalism" (Zinoviev, 1992).

In his youth, Zinoviev developed an interesting epistemology of the "elevation from the abstract to the concrete" (Zinoviev, 1981: 56-59; 2002). Based on the reading of Marx's Capital, his epistemology consisted of moving from an original idealization towards new relationships of a "complex, multilateral, differentiated, dynamic" object, where the original idealization, under certain concrete circumstances, could be falsified but not thereby refuted. As he writes in his later political work,

\begin{abstract}
"a concrete judgment may contradict an abstract one, but there is no dialectical contradiction there. In fact, we have the following two judgments; (1) if one abstracts from certain factors, an object will have a quality 'A', (2) if one considers these factors, the object will have the quality ' $\mathrm{Y}$ ' . . . The dialectical method of thinking emerged at a certain time as a set of logical techniques similar to this one, and not as a doctrine of general laws of being which, by the way, do not exist" (Zinoviev, 1981: 60).
\end{abstract}

Note that we are talking of the contradiction, not of the opposition which Zinoviev thus ousts from dialectics. The result is a method which allows for fixing a certain historical reality forever, without recognizing its internally contradictory structure which would be thus subject to historical overcoming. This "sin" of Marx's Capital (which risks essentializing capitalism) is transposed by Zinoviev in the reality of Soviet communism. Interestingly, this method, even though it denounces negativity, leads, in Zinoviev's sociological and literary work, to the entirely "negativist" picture of reality in the sense that it derides and castigates any current reality, be it Soviet communism, Soviet intelligentsia critical of communism, or Western capitalist society. Negativity is evacuated into the solitary transcendental subject (beautiful soul?), to which it allows to move freely from the rejection of one opposite to the rejection of another.

Zinoviev's disinterest in negativity and opposition as tools of reality analysis and his "organic" thinking are characteristic of the whole tradition that we are now discussing. In the West, it has some striking similarities to the views of Deleuze ${ }^{8}$ and his followers. In Russia, it influenced a number of thinkers who refuse to analyze contemporary Russia in terms other than "totalitarian" or "communist" and perceive any changes (including the change of politico-economic regime!) as superstructural (Levada, Gudkov, Ryklin, and many others).

A view partly similar to that of early Zinoviev is held by yet another soviet dissident philosopher and émigré, Boris Groys. From his works of the Soviet period up to the recent Communist Postscript ${ }^{9}$, Groys emphasized the substantively peculiar character of the Soviet regime which did not coincide with socialism per se, but consisted, according to

8. Particularly if we consider the Anti-Oedipus, and ideas expressed there on the history of Modern capitalism: the latter did not defeat despotism but included it as one of its elements.

9. See reference above. 
him, in the ideocratic and mythopoetic power of this state, which was thus different from the more down-to-earth materialist Western societies. For Groys, the communist regime was "dialectical", by which he understands the ability to incorporate any reality into one's ideological outlook and to behave in an entirely unprincipled way. This caricature of dialectic (which bears traces of an attentive reading of Kierkegaard) has an obvious similarity to the "dialectic" of early Zinoviev. But, symmetrically opposed to Zinoviev's prosaic understanding of communism as "communality", Groys dismissed the socialist aspirations of the Soviet regime and instead emphasized its avant-garde aestheticism. Groys' approach, which had already started with Gesamtkunstwerk Stalin, remains highly influential in post-communist studies; one of the most interesting developments of the same argument has been the work of Evgeny Dobrenko who applies the theory of Baudrillard to the Stalinist Soviet Union and claims that it produced an imaginary that fully replaced the material reality (Dobrenko, 2007).

In the same line of argument, one has to mention a more recent work by Oleg Aronson who combines the arguments of Zinoviev and Groys with the philosophical communism of Nancy and with the late Benjamin's apology of mass culture. Aronson, an erudite connoisseur of film, claims that Soviet cinema (as well as Western mass cinema) created a certain "sensible" communism, which consisted in the making-common of image, not of material things. Aronson thinks that a poetic of "cliché", which is characteristic of mass culture, is paradoxically more "communist" than the authorial techniques of many art house films. Thus, "perception of cinema becomes immanent to the type of commonality where it remains not word and not silence but a communication (relationship to the other that proceeds from the insufficiency of Ego)" (Aronson, 1993: 86-87). ${ }^{10}$

In contrast with the essentially conservative outlooks of both Zinoviev and Groys, Aronson means his socio-aesthetic philosophy in a populist-liberal way; there is a deep communism in the mass culture, and in the life of masses, which is superior to any ideologies of communism or to any political and social institutions and which reflects a normality of life which the state should not infringe upon. In fact, this apology of mass culture ignores the fact that the "shock" which Benjamin detected in it survives inside the habit which trivializes the shock. A Hollywood image does not only stamp the "innocence" of sense with a morally-meant statuary figure, but also keeps reproducing the extreme violence, that is, the violence that expresses and at the same time suppresses the general will and the need to transform or even question reality. Theories that idealistically identify the sensual experience of art with the practical experience in other regions ignore the violence with which art "stamps" the resistant reality of social practice. The same Benjamin whom Aronson uses to prove his doctrine ends the essay on the "mass reproduction of art" with the description of war as a scene of mass destruction, the last spectacle available to the humanity which wants to express itself rather than act (Benja-

10. The reference of Aronson is Dziga Vertov, and he sees the continuity between his work and the Modern mass culture. Interestingly S. Žižek recently evoked the example of Vertov's cinematographic "communism"), even though he does not share Aronson's will to rehabilitate the Modern mass culture: his references, in this article, remain at the level of high art, and we know that Žižek generally has a critical approach to mass cinema. 
min, 2006). On the contrary, the "communist" energy of films like Vertov's consists in their liberation from the power of a cliché; like realist paintings, they show something invisible and unseen, their power thus being a revelatory revolutionary force, not just an education of senses. Žižek, who also uses Vertov's film (and theory) to illustrate "communism" (Žižek, 2010), notes something that Aronson does not; the fact that Vertov's "cinema eye" (in the "Cameraman") shows us the cameraman himself, even though this particular image is not marked or accentuated. The subject remains an element of the flow of things, both a subject and an object of vision. Žižek does not comment further on this detail, although it is crucial in this debate. The image of the cameraman involves reflexivity and subjectivity, and plays a negative role; it is a way to actively liberate the field of vision from the transcendental subject, not to affirm one. But this is the operation of cinema as a critical and revolutionary art with which "mass" culture does not and cannot operate and which thus schould be seen as properly communist.

While all of the described theories of communism are interesting, and certainly more interesting than Soviet official philosophy or the Western theory of "totalitarianism", they may and must be criticized from the Left. All of these theories dismiss the emancipatory socio-political nature of the regime that achieved what it did, not by setting free some age-old chaotic energies of the masses, but through a wide-range destruction of the institutions of private property, and through a democratic revolutionary mobilization of the society. It is clear that many of the phenomena that are deemed to be "communist" in the aforementioned "real communism" tradition are in fact the results of the large-scale destruction of the social link, which allowed a communistic questioning of traditional forms. On the other hand, it is the negativity of the dethroned (but continuous) past and of the open (but imagined and represented) future, which allowed for the epoche of the "massified" image à la Aronson, and for the occasional victories of social imaginary à la Groys and Dobrenko. It is important, however, not to fall into a fetishism of image and to be attentive to this negativity which is a virus of a negative, and therefore politically active, communism.

To understand the "communism" of Soviet society, we need to be attentive to its peculiar melancholic character and, moreover, to the negative condition of the extatic "communality" which ultimately led to the regime's destruction. Moreover, at the background of a motion, be it a collective purposeful activity, an expectation, or mourning, humans become apparent as ground and not figures (cf. the famous example of Sartre with the expectation of meeting Pierre in a café whose inhabitants move into the perceptual background as a result of this (frustrated) expectation (Sartre, 1969: 9-10)).

Paradoxically, any talk of the "communality" or "communism" of Soviet society should start from the consideration of the most non-communist phenomena possible. The Russian people today are among the most atomized and egoist in their values and attitudes. They value individual happiness above all, they do not care about charity, they are apolitical, and they almost never take collective action. Everyday communication among strangers is extremely alienated: a contemporary Russian will rarely excuse oneself if 
s/he kicked you in the crowd, would not say "hi" if s/he leaves next door in your stairwell, etc. If one is in the way of another person, s/he would silently push you or your body part away without saying a word. Russians live in cosy apartments, but usually their stairwells are rotten and in a state of disrepair. Against an obvious objection that this situation is a product of the rogue capitalism of the 1990s, one must immediately rejoin that these traits have existed throughout the conscious life of the generation born in 1970s, and appear as rigid behavioral patterns that the new Western-oriented culture politic tries in vain to revert. In the late Soviet society, these traits coexisted with the intensely communal elements which were subsequently denigrated and now, while still existent, are regarded as an obstacle and residue of the past, while in fact ultra-individualist values are a residue of the past to an even larger degree. What we have to look for instead is an intermediary space or a phenomenon, in which communal life is not brutally opposed to individualism, but joins it, so that a community exists at its strongest in the modus of its own dissolution. At the same time, an individual affirms and values him or herself only when $\mathrm{s} /$ he is reaffirmed and repeated in his /her sheer singular existence by a collective.

Realistically, the anti-communality of today's Russians may be explained by the extreme zeal with which the Soviet state placed families into packed "communal apartments" without permission of the existing tenants, and by the fact that it moved many of these families into private apartments in the 1960s and 1970s, creating conditions for a modest but zealous embourgeoisement. Communism seen as a unilateral collectivism reinforced, with time, a suppressed side of atomistic competitiveness. Thus, the post-communist Russian middle class is a mirror-image of the Western educated class; the latter are atomized by law but strive for some idealistic solidarity, while the former, more united and interdependent physically, consciously defend and institute the newly-acquired individualism.

Is this a proof that Soviet socialism was "totalitarian", but not truly communist? Perhaps this excessive alienation points to something else, and hides a "positive", attractive side.

In the Soviet Union, public space was a space of anarchic freedom, and complete alienation was a guarantee of non-appropriation. The attractively-deserted character of Soviet space is well shown in Soviet art, most famously in Andrey Tarkovsky's film, "The Stalker", with its estranged but mystically utopian industrial ruins as a space where a deep communication becomes possible. However, long before Tarkovsky, the same poetic was elaborated by Andrey Platonov (1899-1951), the greatest Soviet prose writer of the revolutionary generation. There were other theorists and writers before Tarkovsky, such as Lev Vygotsky and Mikhail Baktin who, under the Soviet regime, produced apologies of communism as an ecstatic utopian force that destroyed identities and deliberately created chaos. We can even speak of a communist anti-communist canon of people who in their thought and imagination preserved the constituent (or destituent?) power of communist revolution.

In many of Platonov's allegories of communism (including the builders of a foundation pit, a premature attempt to build "communism" in a small town called Tchevengur, 
or the emancipation of a small Turk tribe called the "Dzhan" wandering in a Central Asian desert), people are shown in alien deserted spaces, in extreme poverty, fatigue, and solitude. In opposition to Marx, communism for Platonov is the regime of poverty and negativity. At the same time, as it is clear biographically and textually that he was a staunch supporter and participant of the Soviet project, becoming probably the deepest internal analyst of the regime.

Tchevengur, in accordance with Badiou's doctrine, is a town where communism is organized by the "prochie", or the unaccounted "rest" of society. The wandering of the Dzhan people ends in their dissolution, when they depart one by one in all directions. Platonov sees communism as both solitude and community ${ }^{11}$, but these two are presented not as an organic development from one to another (as conceived by Virno in the concept of individuation), but as a dialectical tension. For instance, a very characteristic diary note from 1931 reads: "The mystery of prostitution: union of bodies implies a unity of souls, but in the prostitution the unity of souls is so absent, and it is so apparent and terrible, that there is no love, that from surprise, from the fall, from fear - 'unity of souls' starts to emerge" (Platonov, 2006a: 185). At the same time, Platonov presents human sociability on the basis of a literary trope which Olga Meerson called the "non-estrangement" (Meerson, 1997) but which is in fact a counterestrangement, that is, the presentation (and perception by characters) of weird and surprising events (such as a bear working as a blacksmith), as normal occurrences that are not accentuated or marked within the otherwise realistically looking narrative. It is a special sociability that grows from alienation and dissolution and that takes others for granted.

Thus, Platonov's universe of a collective solitude where humans relate to each other non-thematically, as to ground rather than to figure, appears as a utopian communism of senses close to what is described by Aronson. However, it is clear that for Platonov, against Aronson's theory, such communism exists in the framework of radical subjectivization, which implies the questioning of traditional, fixed subjectivity. Platonov's characters are obsessed with finding out who is doing what they are doing. One of them says, in a latent polemic reminiscent of Descartes, "I don't exist here. .... I only think here" (Platonov, 1999: 7; 1994: 13). Another calls himself an non-existent word, "dubject" (a split and idiotic subject) (Platonov, 2006b: 120, 213). ${ }^{12}$ Yet another says "In spite of my selfconsciousness as a right-winger, left-winger, and a reconciliatory quietist, I am still sad, and consider this statement of mine to be insufficient, to be a typical démarche of a class enemy" (Platonov, 2009b: 254). This latter phrase is a parody of the "self-criticism" which was required at that time for Soviet citizens. But for Platonov, it is a genuine movement of subjectivization; a performative self-refutation which is a performative manifestation that the revolutionary subject exists. The same is true of Platonov's image of a "eunuch of the soul", the powerless internal observer in each of us. Valery Podoroga treats this figure as a modernist technique of estrangement, as a phenomenological eye that only sees the

11. See an important book on Platonov's melancholia, by Jonathan Flatley: Flatley, 2008. Flatley, like Aronson, emphasizes the affective being-in-common, not the subjectivity.

12. Cf.: Platonov, 2009. 
external, non-subjective and non-psychological, thus providing for the "absurd" reality of Platonov's novels (Podoroga, 1991). Literally, this eunuch is a castrated part of the soul, a product of self-mutilation by a divided subject who is constantly in struggle against him/ herself and who at the same time successfully produces his/her own desire as powerless. It is the self-criticism and self-subversion that are responsible for the paradoxical solitude of communist subjects on which Platonov insists. We deal not with the solitude of an individual, but of an abject part, which, as such, enters a community with other such parts, and parts of others. To this eunuch of soul, there are many corresponding characters in Platonov. They often metaphorically represent lonely phalluses, such as the eternal wanderer Luy, from Platonov's Tchevengur.

All of this is indicative of the meaning of sadness and solitude in Platonov; they are affects of self-destruction which is needed in order to retroactively create a subjectivity for the ongoing Soviet project. A revolution conceived by intelligentsia for the sake of the "proletariat" then had to build this proletariat and to grow its own roots, requiring a regressive, destructive approach. This is the meaning of the metaphor of the "foundation pit"; the joyful optimistic construction of the future means nothing without all the mourning that it redeems, and needs to be constantly reconstructed.

Again, the inattention and aggression in Russian streets and apartment buildings may simply mean that Russian citizens take other people for granted, as a ground not as a figure. It is completely opposite from the Western European normal behavior vis-à-vis strangers, where an encounter produces a shock of almost disbelief, and the exaggerated rituals of politeness are meant to hide the embarrassment of the encounter itself. As already mentioned, Paolo Virno suggests that communism is a way from the assumed collectivity to "individuation" (Virno, 2004: 64-69). This is an organic version of the coexistence and passage between these two opposites. Alas, a gloomier scenario exists in Russia with the move from an assumed commonality to egoism and cynicism. It still serves as a manifest proof of the pre-existing being-in-common. But, as elsewhere, the newly formed "subjects" do everything to suppress and destroy the ground sociability, the premise of their existence.

Thus, the presumably "totalitarian" Soviet party-state in fact did produce a common space by virtue of its very alienating force: the state property was informally considered "ownerless." This did not help economic development, but did maintain a paradoxical sense of belonging and commonality via the relationship to this ruined state property, although not immediately. This, in a strict sense, is associated with what "common" really means; "res communis omnium" in Roman law was distinct from the "res publica" or "res nullius", because it was a good which belonged to no one (including the Roman people, etc.), and could not be appropriated (as res nullius could be). ${ }^{13}$ One may say that res communis is a mediator between res nullius and res publica; in a sense, it also belongs to no one, and this very non-belonging is protected by the public.

13. Inst. 2.1, 2.1.1, Dig. 1.8.2 pr.-1 (Marcianus), in: Koptev, Lassard, 2013. 
In the Middle Ages ${ }^{14}$, common land could belong to a feudal lord, but he did not have complete sovereignty over it; property, in such cases, did not exclude the right of usage by others. This is also the case with public property in today's Western countries. But, the fact that this is property of the people, allowing for its usage, policing is necessary, that is, prohibition of starting fires, drinking, smoking, the installation of cameras, etc. In the case of the res communis omnium, the legal rule was rather closer to the Schmittean right of exception; law excluded a territory from the regime of property.

Now, how do we understand this communist anti-communism in the Soviet Union? There are at least two obvious explanations.

The first explanation is that Soviet socialism was a weird way to block the modernization of social relations in the spirit of bourgeois Enlightenment and, being unable to suggest anything new, managed to freeze a certain pre-Modern sociability of a mutually suspicious crowd and family-like networks of kinship and friendship, using clientelist networks for economic activity and living in a perpetual communion of feast and alcohol. This version is close to Zinoviev's "communality", except that the features in question are not collectivist. Soviet society on an everyday basis was less communal than Western society (where, for instance, the regular co-habitation of "roommates" or other previously not acquainted individuals exists as a normal institution for young people, and does not cause a large social problem or a dissident discourse, as in the case of Soviet communal apartments).

The second explanation, paradoxical in nature, is that the cunning of history made the quasi-theocratic Soviet party-state a placeholder for the profane sacrality of a terra and res nullius, which was strangely at the same time a res communis. This version would be close to Groys's theological parallels, except that it is the negative, apophatic elements of religion that are emphasized.

In both cases, there is a danger of taking these situations for granted, ignoring their eventful, catastrophic coordinates, or dismissing them as archaic.

In fact, communism is not necessarily anything "nice", and even not necessarily anything "collectivist". Both its utopian force and its force of a real movement build on the possibility of immediate solidarity and on the power of disrupting and dissolving the social body, exposing humans to each other in their extreme solitude. It is this power that makes communism a threat and a hope for the status quo. There is a potential of revolution and subversion, and at the same time, is an idea of a society which would not correspond to any model or idealist definition. In fact, communism would actively destroy any such model, building instead both the structures of social dissolution and the structures of aleatoric sociability. The current non-being of solidarity in post-communist countries may well correspond to the temporal non-being of communism which remains a "specter", having passed away without having ever been there. This is quite natural for the negativity as such, which is always unstable and fleeting but which, at the same time,

14. Cf.: Moulier Boutang, 2010. 
returns in its very repression. ${ }^{15}$ The culture of the collective solitude formed in the authoritarian environment may also be used, in an inverted way, to invent an alternative to the bourgeois sociability.

In conclusion, it is important to treat communism politically and subjectively, and to maintain it as an alternative to, and a liberating abolition of the existing state of affairs. We can admit that in some sense we are all already communists. Political institutions play an often complex yet indirect role in the development of a communist society. But without political subjectivization, communism remains an ethically neutral and ambivalent process which can lead, politically, not only to self-management, but sometimes to the authoritarian destruction of the social link, or even to the fascist-like hyper-identification of a collective. This said, the political institutions of communism should somehow be themselves "negative" and foster the destruction of identities and the invention of new unclassifiable entities.

A parallel may be drawn between the concept of communism and the concept of "democracy". Claude Lefort famously argued that democracy is a regime where the place of supreme power is temporarily left empty, and special care is taken to regularly empty it out (Lefort, 1986). It is analogous with communism, at least in some crucial spheres; private property should not just be forbidden, but should be actively resisted as an informal social institution. The partiality and ideality of the concept of democracy, which subordinates life to law, covers up for authoritarianism in a corporation or in dealing with non-citizens, as well as serves to demobilize people and consider them only as passive bearers of interest, may be criticized. However, we see that in today's world there are democratic states (like France or Italy) with numerous mass illegal or informal protests led by a non-systemic opposition and directed against the existing regime. These states certainly do not encourage their citizens to do so, but there is something about these states' liberal "democracy" that provokes some individuals to go against it in a "democratic" way. Jacques Rancière, an influential apologist of Western democracy, uses the argument that democracy starts where there are new unrecognized subjects (les "sans-parts") emerging to contest the status quo (Rancière, 1995). In this sense, what we mean by communism is a more radical and less formal version of the same thing that the left-wing understanding of democracy entails, that is, a regime which is constantly capable of self-overcoming.

There must be ways to preserve the subversive, ecstatic character of communist constituent power, even at the price of its potential destructiveness. The current socio-political situation shows, furthermore, that there is a need for constantly educating citizens, whether in a democracy or with communism (which is a stronger formulation of democracy). In not assuming that egoism and private escapism are in human nature, we nevertheless see what the dominant ideology successfully imposes this style of action on people. Moreover, the negative dissolving force of communism itself risks producing apathetic "last men" at the moment when the ideology is stopped. An effort must be made to make the communist background of the current atomization and apathy evident. But,

15. On these and other features of negativity in politics, see my La Révolution négative (Magun, 2009). 
any educational posture will inevitably produce a counter-effect of overturning of the educators. So, perhaps a communist government should be truly dialectical (as opposed to the pseudo-dialectical liberal state, as well as to the ideocratic dogmatism of the Soviet state to which Groys falsely attributes a dialectic, which he identifies with nonsense). Such a government should be harsh, but plastic at the same time, constantly preparing its own downfall.

\section{References}

Aronson O. (1993) Metakino [Metacinema], Moscow: Ad Marginem.

Badiou A. (2006) Being and Event, New York: Continuum.

Badiou A. (2007) Destruction, Negation, Subtraction: On Pier Paolo Pasolini. Available at: http://www.16beavergroup.org/mtarchive/archives/oo2701print.html (05.10.2012).

Badiou A. (2009) L'hypothèse communiste, Paris: Lignes.

Benjamin W. (2006) The Work of Art in the Age of Its Technological Reproducibility. Selected Writings, vol. 3: 1935-1938, Cambridge: Harvard University Press, pp. 101-133.

Dobrenko E. (2007) Political Economy of Socialist Realism, New Haven: Yale University Press.

Flatley J. (2008) Affective Mapping, Cambridge: Harvard University Press.

Gastev A. (1971) Poezia rabochego udara [Poetry of the Worker's Blow], Moscow: Khudozhestvennaya literatura.

Grandjonc J. (1983) Quelques dates à propos des termes communiste et communisme. Mots, vol. 7, no 1, pp. 143-148.

Groys B. (2010) The Communist Postscript, London: Verso.

Hölderlin F. (1989) Le communisme des esprits, Paris: L'Herne.

Hölderlin F. (1988) Remarks on Antigone. Essays and Letters on Theory (ed. T. Pfau), New York: SUNY Press, pp. 109-116.

Kant I. (1991) Idea for a Universal History with a Cosmopolitan Purpose, Cambridge: Cambridge University Press.

Koptev A., Lassard Y. (eds.) (2013) The Roman Law Library. Available at: http://droitromain.upmf-grenoble.fr (05.10.2013).

Laclau E. (2004) Can Immanence Explain Social Struggles? Empire's New Clothes: Reading Hardt and Negri (eds. P. Passavant, J. Dean), New York: Routledge, pp. 21-30.

Lefort C. (1986) Essais sur le politique (XIXe - XXe siècles), Paris: Seuil.

Magun A. (2009) La Révolution négative, Paris: Harmattan.

Meerson O. (1997) Svobodnaya Vesch: Poetika neostraneniya u Andreya Platonova [A Free Thing: The Poetics of Re-Familiarization in Andrei Platonov's Work, in Russian], Oakland: Berkeley Slavic Specialties.

Marx K. (1975a) Communism and the Augsburg Allgemeine Zeitung. Collected Works, vol. 1, Moscow: Progress Publishers, pp. 215-221.

Marx K. (1975b) On the Jewish Question. Collected Works, vol. 3, Moscow: Progress Publishers, pp. 146-174. 
Marx K., Engels F. (1975a) Contribution to the Critique of Hegel's Philosophy of Right. Collected Works, vol. 3, Moscow: Progress Publishers, pp. 3-129.

Marx K., Engels F. (1975b) German Ideology. Collected Works, vol. 5, Moscow: Progress Publishers, pp. 19-584.

Marx K., Engels F. (1976) Manifesto of the Communist Party. Collected Works, vol. 6, Moscow: Progress Publishers, pp. 477-519.

Michelet J. (1979) Histoire de la Révolution française, vol. 1, Paris: Robert Laffont.

Moulier Boutang Y. (2010) Les nouvelles clôtures: nouvelles technologies de l'information et de la communication ou la révolution rampante des droits de propriété. Available at: http://fr.pekea-fr.org./p.php?c=comm/8-7-Y-MOULLIERBOUTANG.html (05.10.2013).

Nancy J.-L. (1991) The Inoperative Community, Minneapolis: The University of Minnesota Press.

Nancy J.-L. (2010) Communisme - le mot. L'idée du communisme (eds. A. Badiou, S. Žižek), Paris: Lignes, pp. 197-214.

Negri A., Hardt M. (200o) Empire, Cambridge: Harvard University Press.

Platonov A. (1994) The Foundation Pit, Evanston: The Northwestern University Press.

Platonov A. (1999) Kotlovan [The Foundation Pit], Moscow: Gudyal Press.

Platonov A. (2006a) Zapisnye knizhki [Notebooks], Moscow: IMLI RAN.

Platonov A. (2006b) Chevengur [Chevengur]. Available at: http://imwerden.de/cat/modules.php? name=books\&pa $=$ showbook \&pid=686 (10.11.2010).

Platonov A. (2009a) Chevengur, Madrid: Cátedra.

Platonov A. (2009b) Zabluzhdenie na rodine kompota [Delusion in the Motherland of Compote]. Arkhiv A. Platonova [A. Platonov's Archive], Moscow: IMLI, pp. 250-254.

Podoroga V. (1991) The Eunuch of the Soul: Positions of Reading and the World of Platonov. South Atlantic Quarterly, vol. 90, no 2, pp. 357-408.

Rancière J. (1995) La mésentente: politique et philosophie, Paris: Galilée.

Sartre J.-P. (1969) Being and Nothingness: Essay on Phenomenological Ontology, London: Routledge.

Virno P. (2004) A Grammar of the Multitude: For an Analysis of Contemporary Forms of Life, London: Semiotext(e).

Zinoviev A. (1981) Communisme comme réalité, Paris: Juillard, Age d'Homme.

Zinoviev A. (1992) Perestroika in Partygrad, New York: Peter Owen.

Zinoviev A. (2002) Voskhozhdenie ot abstraktnogo k konkretnogo [Elevation from the Abstract to the Concrete], Moscow: Institute of Philosophy.

Žižek S. (2010) Remarques pour une définition de la culture communiste. L'idée du communisme (eds. A. Badiou, S. Žižek), Paris: Lignes, pp. 316-347. 